\title{
3D NUMERICAL MODEL OF THE SPHERICAL PARTICLE SALTATION IN A CHANNEL WITH A ROUGH FIXED BED
}

\author{
NIKOLAY LUKERCHENKO, SIARHEI PIATSEVICH, ZDENEK CHARA, PAVEL VLASAK*
}

Institute of Hydrodynamics of Academy of Sciences of the Czech Republic, v. v. i., Pod Patankou 30/5, 16612 Prague 6, Czech Republic; Mailto *corresponding author: vlasak@ih.cas.cz, Phone: +420 221403266, Fax: +420 221403492

\begin{abstract}
The paper describes a 3D numerical model of the spherical particle saltation. Two stages of particle saltation were distinguished - the particle free motion in water and the particle-bed collision. The particle motion consists of the translational and rotational particle motion. A stochastic method of calculation of the particle-bed collision was developed. The collision height and the contact point were defined as random variables. Impulse equations were used and the translational and angular velocity components of the moving particle immediately after the collision were expressed as functions of the velocity components just before the collision. The dimensionless coefficients of the drag force and drag torque were determined as functions of both translational and rotational Reynolds numbers. The model is in good agreement with known experimental data. Examples of calculation of the particles' lateral dispersion and the mean absolute values of the deviation angle of the particle trajectory are presented.
\end{abstract}

KEY WORDS: 3D Saltation Model, Bed-Load Transport, Particle-Bed Collision, Particle Rotation, Particle Lateral Dispersion.

Nikolaj Lukerchenko, Siarhei Piatsevich, Zdeněk Chára, Pavel Vlasák: 3D NUMERICKÝ MODEL SALTACE KULOVITÉ ČÁSTICE V KORYTĚ S PEVNÝM DRSNÝM DNEM. J. Hydrol. Hydromech., 57, 2009, 2; 37 lit., 7 obr.

Studie popisuje 3D numerický model saltačního pohybu kulovité částice, v němž jsou uvažována dvě fáze saltačního pohybu - volný pohyb částice v proudící vodě a kolise částice se dnem. Model počitá s translačním i rotačním pohybem částice. Byla vyvinuta stochastická metoda výpočtu kolise částice se dnem. Kolizní výška a kontaktní bod byly definovány jako náhodné proměnné. Byla použita soustava momentových rovnic a složky translační a rotační rychlosti pohybující se částice po kolizi byly vyjádřeny jako funkce složek rychlosti těsně před kolizí. Bezrozměrné koeficienty odporu částice a odporu rotující částice byly určeny jako funkce translačního i rotačního Reynoldsova čísla částice. Výsledky modelu jsou v dobré shodě se známými experimentálními daty. Studie presentuje př́klady výpočtu príičné disperze částice a střední absolutní hodnoty deviačního úhlu trajektorie částice.

KLÍČOVÁ SLOVA: 3D model saltace, pohyb splavenin, kolise částice-dno, rotace částic, př̌čná disperze částic.

\section{Introduction}

Numerical models of the bed-load transport, including its saltation mode, are usually twodimensional (e.g. Reizes (1978); Murphy and Hooshiari (1982); Van Rijn (1984); Wiberg and Smith (1985); Nino and Garcia (1994); Lee et al. (2000); Kholpanov and Ibyatov (2005); Lukerchenko et al. (2006)). However, from the physical point of view, the saltation process is essentially three-dimensional. In particular, particle-bed collision is the main mechanism producing the lateral dispersion of the saltating particles (Nino and Garcia, 1998; Chara and Vlasak, 2000), which can be described only by the 3D pattern of particle motion. Similarly, the particle motion in a channel with a laterally sloping bed can be calculated only using a 3D model (Lukerchenko et al., 2008b).

Sekine and Kikkawa (1992), Schmeeckle and Nelson (2003) and Lee et al. (2006) developed 3D models, which do not take into account particle rotation. However, the experiments of Lee and Hsu (1994) showed that the particle angular velocity could reach values of a few tens of revolutions per 
second during the saltation. The rotation of a particle moving in a fluid leads to an additional lateral force - the Magnus force. As shown below, in some cases, the Magnus force reaches values that are comparable with values of the drag force.

However, even for small values of the Magnus force, it plays an important role in the migration of particles towards or from the bed, because the particles travel relatively very short distances in order to approach the bed and even a weak force would be sufficient to induce them to travel such short distances (e.g., Michaelides, 2003). Kurose et al. (2001) showed experimentally that "the effect of particle rotation should be taken into account in predicting the particle trajectory in the turbulent boundary layer, especially for the high particle Reynolds number".

In the present paper, a 3D numerical model of a single spherical particle saltation in a channel with a fixed rough bed is developed. The particle rotation is taken into account. This model is based on the well-known 2D model of Nino and Garcia (1994). They, using the Mei et al. (1991) form of the Lagrangian governing equations (introduced by Maxey and Riley, 1983) for the motion of a small spherical particle in an unbounded fluid, proposed the system of equations for 2D motion of a sediment particle in a turbulent boundary layer. Lukerchenko et al. (2006) introduced the particle rotation and the vector form of this system of equations, which also allows the use of this system for the 3D case.

The particle rotation changes the boundary layer on the particle surface and thereby also the values of the drag force. In the present model, the correction of the drag force coefficient as well as the drag torque coefficient is performed according to the experimental data of Lukerchenko et al. (2008a), which expressed the effect of both the translational and rotational Reynolds numbers on these coefficients.

Let us suppose that the particle contacts the channel bed only at one point during the collision and define the contact point as the point of the particle surface, which is in contact with the bed at the moment of the relevant collision. The particle-bed collision is a random process because the bed surface is irregular. Therefore, the coordinates of the particle centre at the moment of collision as well as the contact point coordinates are also random variables. A new stochastic method for their calculation in the $3 \mathrm{D}$ case is proposed in this paper.
In the present model, similarly to most models of saltation, the turbulent fluctuations are neglected since, according to Bagnold (1973) and Francis (1973), the effect of turbulent fluctuations doesn't play any considerable role in the saltation mode of bed-load transport. It was also confirmed by the recent experiments of Ancey et al. (2002) with glass and steel beads with diameters of $3 \mathrm{~mm}$ and $6 \mathrm{~mm}$ that "the trajectory shape is fairly smooth and is apparently not affected by turbulent variations in the surrounding fluid."

In the present paper, the comparison of the calculated data with experiments of Nino and Garcia (1998) conducted with natural sand of $0.5 \mathrm{~mm}$ in diameter shows that, even for such relatively small particles, the turbulent fluctuations' effect on the saltation parameters is insignificant.

In agreement with the physical nature of saltation, the numerical model contains two successive stages. The first one consists of the free particle motion in water above the channel bed; the second one is the particle-bed collision. The vectors of the translational and angular velocities of the particle immediately after the collision are used as the initial conditions for the calculation of the trajectory of the particle moving freely in water and therefore they must be calculated from their values immediately before the collision. The impulse equations at the contact point can be used for this purpose if the contact point is known (e.g. Matsumoto and Saito, 1970; Tsuji et al., 1985a; Oesterle, 1989; Crowe et al., 1998; Schmeeckle et al., 2001; Lukerchenko et al., 2006).

\section{The 3D mathematical model of the spherical particle motion in fluid}

If the particle concentration in fluid is sufficiently low, a single particle motion can represent the motion of all particles and the influence of the particles on the fluid flow as well as mutual particle-particle interaction can be neglected.

Let us consider a saltation process of a single solid spherical particle in an open channel with a rough bed. A homogeneous spherical rotating particle of diameter $d_{p}$ and density $\rho_{p}$ moves in the fluid of density $\rho$ and kinematic viscosity $v$ in the channel with the bed roughness $k_{s}$. The system of equations for the calculation of the spherical particle motion in fluid in the 2D case (Lukerchenko et al., 2006) was written in the vector form and, therefore, it can also be used in the 3D case with only the minor differences listed below. 
The downstream, upward, and transverse coordinates are denoted as $x, y$, and $z$, respectively. The following vectors are three-dimensional: the radiusvector of the particle centre of mass $\boldsymbol{r}_{\boldsymbol{O}}\left(x_{p}, y_{p}, z_{p}\right)$, the vector of the velocity of the particle centre of mass $\boldsymbol{v}\left(v_{x}, v_{y}, v_{z}\right)$, the vector of the fluid velocity $\boldsymbol{v}_{\boldsymbol{f}}$ $\left(v_{f x}, v_{f y}, v_{f z}\right)$, the vector of angular velocity of the particle rotation around its diameter $\boldsymbol{\omega}\left(\omega_{x}, \omega_{y}, \omega_{z}\right)$, the drag force $\boldsymbol{F}_{\boldsymbol{D}}$, the force due to added mass $\boldsymbol{F}_{\boldsymbol{m}}$, the submerged gravitational force $\boldsymbol{F}_{\boldsymbol{g}}$, the Basset history force $\boldsymbol{F}_{\boldsymbol{B}}$, the Magnus force $\boldsymbol{F}_{\boldsymbol{M}}$, and the drag torque of viscous forces acting on the particle $\boldsymbol{M}$.

The particle motion in fluid is determined by two dimensionless parameters: translational Reynolds number (or Reynolds number) $\operatorname{Re}=\left|\boldsymbol{v}_{\boldsymbol{R}}\right| d_{p} / v$ and rotational Reynolds number $R e_{\omega}=\left|\omega_{R}\right| r_{p}^{2} / v$, where $v_{\boldsymbol{R}}=\boldsymbol{v}-\boldsymbol{v}_{\boldsymbol{f}}$ is the vector of particle-fluid relative velocity, $\omega_{R}=\omega-0.5 \operatorname{rot} \boldsymbol{v}_{f}$ is the particle relative angular velocity, and $r_{p}=0.5 d_{p}$ is the particle radius.

For the description of the translational and rotational particle motion in fluid, another pair of the independent dimensionless parameters is sometimes used: the Reynolds number Re and particle dimensionless angular velocity $\Gamma=\left|\omega_{R}\right| r_{p} / \boldsymbol{v}_{\boldsymbol{R}} \mid$ (e.g. Oesterle and Dinh Bui, 1998; Tsuji et al., 1985b). Both pairs are equivalent since $\Gamma=2 \mathrm{Re}_{\omega} / \mathrm{Re}$.

The formulas for the drag force $\boldsymbol{F}_{\boldsymbol{D}}$ and drag torque $\boldsymbol{M}$ are defined using the dimensional analysis and contain the dimensionless drag force coefficient $C_{D}$ and drag torque coefficient $C_{\omega}$, respectively. If a spherical particle moves in fluid and simultaneously rotates around its diameter, these dimensionless coefficients depend on both the Reynolds number Re and the rotational Reynolds number $\operatorname{Re}_{\omega}$ (Lukerchenko et al., 2008a):

$$
\begin{aligned}
& C_{D}=C_{D 0}\left(1+0.065 \mathrm{Re}_{\omega}^{0.3}\right), \\
& C_{\omega}=C_{\omega 0}\left(1+0.0044 \mathrm{Re}^{0.5}\right),
\end{aligned}
$$

where $C_{D 0}=C_{D 0}(\mathrm{Re})$ is the drag force coefficient of a not rotating spherical particle - a well-known function of Re (see e.g. Nino and Garcia, 1994), and $C_{\omega 0}=C_{\omega 0}\left(\operatorname{Re}_{\omega}\right)$ is the drag torque coefficient of a spherical rotating particle in the calm fluid. It is a function of the rotational Reynolds number ( $\mathrm{Sa}$ watzki, 1970).

The translational movement of the solid sphere with a simultaneous rotation in the viscous fluid induced the lateral force known as Magnus force:

$\boldsymbol{F}_{\boldsymbol{M}}=C_{M} \Omega \rho\left[\omega_{\boldsymbol{R}}, \boldsymbol{v}_{\boldsymbol{R}}\right]$, where $C_{M}$ is the dimensionless Magnus force coefficient, and $\Omega$ is the particle volume.

The theoretical analysis of the Magnus force was performed by Rubinov and Keller (1961) for Re $<<$ $1, \operatorname{Re}_{\omega}<<1$. They deduced that $C_{M}=3 / 4$. Goldshtik and Sorokin (1968) derived theoretically that $C_{M}=$ $=2$ for $\operatorname{Re}>>1, \operatorname{Re}_{\omega}>>1$. However, the experimental values of this coefficient were found more than order less than the theoretical ones (e.g. Barkla and Auchterlonie, 1971; Tsuji et al., 1985b).

For the intermediate Reynolds numbers $10 \leq \mathrm{Re}$ $\leq 140$ and $1.25 \leq \operatorname{Re}_{\omega} \leq 105$ (i.e. $1 \leq \Gamma \leq 6$ ), the following convenient relationship for the Magnus force coefficient was suggested by Oesterle and Dinh Bui (1998) based on the experimental investigation:

$$
\begin{aligned}
& C_{M}=(3 / 8 \Gamma)[0.45+(2 \Gamma-0.45) \\
& \left.\exp \left(-0.075 \Gamma^{0.4} \operatorname{Re}^{0.7}\right)\right] .
\end{aligned}
$$

In the present model, this expression is used for the calculation of the Magnus force coefficient.

\section{The 3D numerical model of the particle-bed collision}

Let us consider a spherical homogeneous particle (see Fig. 1) moving in a channel with a rough bed and at the given moment having the translational velocity $\boldsymbol{v}\left(v_{x}, v_{y}, v_{z}\right)$ and the angular velocity $\boldsymbol{\omega}\left(\omega_{x}\right.$, $\left.\omega_{y}, \omega_{z}\right)$. The particle centre is at the point $O_{p}\left(x_{p}, y_{p}\right.$, $z_{p}$ ), and the rough bed is characterized by the bed roughness $k_{s}$, which represents the largest size of the local protrusions and depressions that have the unordered and random nature. The plane $L$ in Fig. 1 represents the bed level - the level of the local depressions, or, in other words, the surface spaced through the lowest points of the local bed depressions. Let us consider a part of the bed in which this surface can be considered as flat.

The collision height $h_{c}$ is defined as the distance between the particle centre and the bed level at the moment of the collision. The collision height can change from $r_{p}$ to $\left(r_{p}+k_{s}\right)$. A random-number generator can be used to define its value. The calculation of the particle trajectory is made until $y_{p}>h_{c}$. The condition $y_{p}=h_{c}$ corresponds with the moment of the collision and then the calculation of the particle-bed collision should be carried out. The components of vectors of the translational $\boldsymbol{v}\left(v_{x}, v_{y}, v_{z}\right)$ and angular $\boldsymbol{\omega}\left(\omega_{\mathrm{x}}, \omega_{y}, \omega_{z}\right)$ particle velocities immediately before the collision, known from the calculation of the particle free motion in fluid, are used to calculate their values immediately after the colli- 
sion, which become the initial conditions for the calculation of the next particle trajectory.

The particle-bed collision can be calculated unambiguously if a contact point is known. The contact zone is the set of all the contact points that are possible for the given collision. The contact zone should be determined and the contact point should be chosen from the contact zone in a random way; then the transformation of the coordinate system Oxyz should be made to obtain the impulse equations in the simplest form. The means of defining the final collision coordinate system are described below.

The angles $\theta$ and $\varphi$ (see Fig. 1) can be calculated from the following equations:

$\operatorname{tg} \varphi=v_{z} / v_{x}$ and $\cos \theta=v_{y} /\left(v_{x}^{2}+v_{y}^{2}+v_{z}^{2}\right)^{0.5}$.

(5 and 6)

The transformation from the $O x y z$ coordinate system to the collision coordinate system, Cin $\eta$, with the origin at the contact point $C$, will be achieved through five elementary transformations of the coordinate system. After each transformation, the vectors $\boldsymbol{v}$ and $\boldsymbol{\omega}$ are recalculated in the new coordinate system.

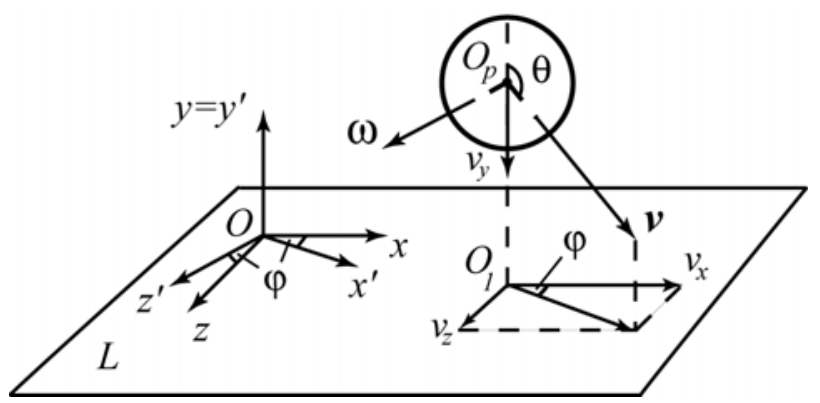

Fig. 1. The particle and the channel bed level before the collision.

Obr. 1. Č́stice a dno kanálu před kolizí.

\subsection{Definition of the contact zone}

The contact zone will be defined in the case $k_{s}=O\left(d_{p}\right)$. For the saltation of natural sand particles in water, the mean value of the incident angle to the bed level is usually about $8-15$ degrees (e.g. Nino et al., 1994; Nino and Garcia (1998)), and the bedparticle collision is most often oblique.

For the 2D collision pattern (Lukerchenko et al., 2006), it was supposed that the contact with the bed is possible only at any point of the arc $E O_{2} D$ (see Fig. 2a) on the particle surface. The particle-bed contact at the point $D$ corresponds with a central impact and at the point $E$ corresponds with a tangential impact.

Similarly, let us suppose for the 3D case that the points of the spherical segment $E O_{2} D$ (see Fig. 2a) are the points at which the particle can contact the bed, i.e. this segment is the contact zone.

\subsection{The first transformation}

First, if the coordinate system $O x y z$ is turned through angle $\varphi$ around the $y$ axis (Fig. 1), it is changed to $O x^{\prime} y^{\prime} z^{\prime}$. In the new $O x^{\prime} y^{\prime} z$ coordinate system, the translational velocity vector $\boldsymbol{v}$ is parallel to the coordinate plane $O x^{\prime} y^{\prime}$. Since the components of a vector are generally independent of the coordinate origin, let us transfer the coordinate origin from the point $O$ to point $O_{p}$ and the coordinate system changes to $O_{p} x^{\prime} y^{\prime} z^{\prime}$ (see Fig. 2a).

\subsection{The second transformation: calculation of the contact point}

Let us turn the $O_{p} x^{\prime} y^{\prime} z$ ' coordinate system around axis $O_{p} z^{\prime}$ by angle $\psi=3 \pi / 4-\theta$ (see Fig. $2 \mathrm{a})$. In the new coordinate system $O_{p} x " y$ " $z$ ", the contact zone is symmetrical with respect to the $O y^{\prime \prime}$ coordinate axis.

The arbitrary point $C$ of the contact zone, i.e. of the spherical segment $E O_{2} D$, is determined by two angles $-\chi=\angle F O_{3} D \quad(0 \leq \chi<2 \pi)$ and $\gamma=\angle \mathrm{CO}_{p} \mathrm{O}_{2} \quad\left(0 \leq \gamma \leq \gamma_{0}=\pi / 4\right)$. Since there is a certain probability that each point of the contact zone will be the contact point, both angles are random variables and can be determined using a random-number generator.

\subsection{The third and fourth transformations}

Let us turn the $O_{p} x " y$ " $z$ " coordinate system around axis $O_{p} y$ " by the angle $\chi$ and then turn the new $O_{p} x$," $y$," $z$ "," coordinate system around axis $O_{p} z^{\prime \prime \prime}$ by angle $\gamma$. If the coordinate origin is moved to the contact point $C$, the new coordinate system $C \tau$ ' $n$ ' $\eta$ ' is established (see Fig. 2b). The coordinate vectors $\boldsymbol{\tau}^{\prime}$ and $\boldsymbol{\eta}^{\prime}$ are in the plane tangent to the particle surface in the contact point $C$ and the coordinate vector $\boldsymbol{n}^{\prime}$ is normal to it. In the $C \tau^{\prime} n^{\prime} \eta \eta^{\prime}$ coordinate system, the particle translational velocity vector is $v^{\prime}\left(v_{\tau}^{\prime}, v_{n}^{\prime}, v_{\eta}^{\prime}\right)$ and the particle angular velocity vector is $\omega^{\prime}\left(\omega_{\tau}^{\prime}, \omega_{n}^{\prime}, \omega_{\eta}^{\prime}\right)$. The components of the velocity vectors can be determined from the formulas describing the above-mentioned transfor- 

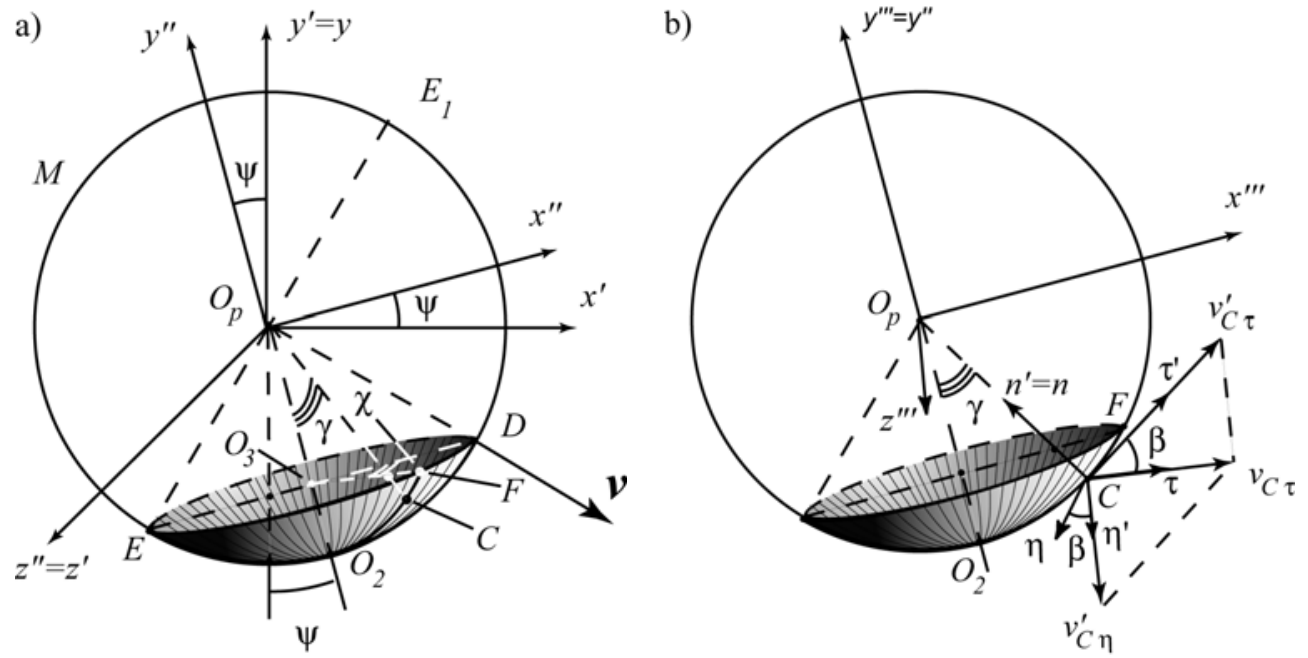

Fig. 2. The definition of the contact zone and the collision coordinate system.

Obr. 2. Definice kontaktní zóny a kolizního systému souřadnic.

mations and the velocity of the contact point $C$ is given by Euler's formula:

$v^{\prime}{ }_{C}=v^{\prime}+\left[\omega^{\prime}, r^{\prime}\right]$,

where $\boldsymbol{r}^{\prime}=\boldsymbol{O}_{p} \boldsymbol{C}=\left(0,-r_{p}, 0\right)$. Hence, the components of velocity vector $\boldsymbol{v}_{C}^{\prime}$ are

$v_{C \tau}^{\prime}=v_{\tau}^{\prime}+r_{p} \omega_{\eta}^{\prime}$,

$v_{C n}^{\prime}=v_{n}^{\prime}$,

$v_{C n}^{\prime}=v_{\eta}^{\prime}-r_{p} \omega_{\tau}^{\prime}$.

They define the angle $\beta$ as $\operatorname{tg} \beta=v^{\prime}{ }_{C \eta} / v^{\prime}{ }_{C \tau}$.

\subsection{The fifth transformation: definition of the collision coordinate system}

When the $C \tau^{\prime} n \eta^{\prime} \eta$ ' coordinate system is turned around the axis $C n$ ' by the angle $\beta$ (see Fig. $2 b$ ), the new coordinate system, $\mathrm{C} \tau \mathrm{n} \eta$, is defined and the contact point velocity vector $\boldsymbol{v}_{C}$ becomes part of the $C \tau n$ coordinate plane. Its tangential component is parallel to the coordinate axis $C \tau$ and its normal component to the contact surface is parallel to the axis $C n$. In the $C \tau n \eta$ coordinate system, the particle translational velocity vector immediately before the collision is $\boldsymbol{v}^{-}\left(v_{\tau}^{-}, v_{n}^{-}, v_{\eta}^{-}\right)$and, similarly, the particle angular velocity vector before the collision is $\omega^{-}\left(\omega_{\tau}^{-}, \omega_{n}^{-}, \omega_{\eta}^{-}\right)$. The $C \tau n \eta$ coordinate system is the collision coordinate system in which the impulse equations can be written in the simplest form.

\subsection{Calculation of the translational and angular velocities immediately after the collision}

In the collision coordinate system $C \tau n \eta$, the impulse equations are

$$
\left\{\begin{array}{l}
\left(m+\lambda_{11}\right)\left(v_{\tau}^{+}-v_{\tau}^{-}\right)=I_{\tau}, \quad J\left(\omega_{\eta}^{+}-\omega_{\eta}^{-}\right)=r_{p} I_{\tau}, \\
\left(m+\lambda_{11}\right)\left(v_{n}^{+}-v_{\bar{n}}\right)=I_{n}, \quad v_{n}^{+}=-e v_{n}^{-}, \\
I_{\eta}=0, \quad v_{\eta}^{+}=v_{\eta}^{-}, \\
\omega_{\tau}^{+}=\omega_{\tau}^{-}, \quad \omega_{n}^{+}=\omega_{n}^{-},
\end{array}\right.
$$

where $\boldsymbol{v}^{+}\left(v_{\tau}^{+}, v_{n}^{+}, v_{\eta}^{+}\right)$is the particle translational and $\omega^{+}\left(\omega_{\tau}^{+}, \omega_{n}^{+}, \omega_{\eta}^{+}\right)$- the particle angular velocity immediately after the collision, respectively. $\boldsymbol{I}\left(I_{\tau}, I_{n}\right.$, $I_{\eta}$ ) is the impulse of the forces acting on the particle during the collision, $m-$ the particle mass, and $\lambda_{11}$ is the added mass of the moving particle. The constant $e$ is the restitution coefficient, which depends, particularly, on the materials of the moving particle and of the bed surface and varies from 0 to 1 .

The first four formulas of Eq. (11) are equivalent to those valid for the 2D case (Lukerchenko et al., 2006) and the last four formulas are trivial. Therefore, the system of equations for the 2D model can also be used for the 3D model.

After the calculation of the vectors of translational and angular particle velocities immediately after the collision and backward transformations of them to the coordinate system $O x y z$, these vectors can be used as the initial conditions for the next particle trajectory calculation.

The numerical solution of the system of equations describing the particle motion, particle-bed collisions and particle trajectory is described in the Appendix A: Algorithm of the particle trajectory calculation. 


\section{Results of calculations}

The calculations were carried out for the saltating particles of sizes varying from relatively small particles of about $0.5 \mathrm{~mm}$ in diameter (for the comparison with the experimental data of Nino and Garcia, 1998) to relatively large particles of $6 \mathrm{~mm}$ in diameter.

The initial conditions were: $x=z=0 ; y=h_{0}$ (usually, $\left.h_{0}=3 d_{p}\right) ; v_{x}=v_{f x} ; v_{y}=v_{z}=0 ; \omega_{x}=\omega_{y}=0$; $\omega_{z}=0.5\left|\operatorname{rot} \bar{v}_{f}\right|=-\frac{1}{2} \frac{\partial v_{f x}}{\partial y}=-\frac{u_{*}}{2 k y}$

(where $u *$ is the shear velocity; $k=0.4$ is the Karman constant). In this case, the drag force, drag torque, and Magnus force are zero in the initial moment. The number of particle hops in the calculations was from a few hundreds to a few thousands and therefore the initial conditions do not play any role in the mean values of the saltation parameters and their standard deviations.

For the restitution coefficient, the formula

$e=0.75-0.25 \tau_{*} \tau_{*}$,

derived experimentally by Nino and Garcia (1998), was used. Here, the ratio $\tau_{*} \tau \tau_{c}$ is the transport stage, $\tau_{*}=u_{*}^{2} /\left[\mathrm{g} d_{p}\left(\rho_{p}-\rho\right) / \rho\right]$ is the dimensionless bed shear stress, $\tau_{*_{c}}$ is the dimensionless critical shear stress for the sediment motion, and $g$ is the gravitational acceleration.

\subsection{The distribution of the forces acting on the particle}

The magnitudes of the drag force $\boldsymbol{F}_{\boldsymbol{D}}$, added mass force $\boldsymbol{F}_{\boldsymbol{m}}$, Magnus force $\boldsymbol{F}_{\boldsymbol{M}}$, and Basset history force $\boldsymbol{F}_{\boldsymbol{B}}$ acting on the particle during one arbitrary hop and the typical particle trajectory are illustrated in Fig. 3. Since the submerged gravitational force $\boldsymbol{F}_{\boldsymbol{g}}$ is constant during the saltation process, it was used as a parameter suitable for setting up dimensionless forms of the remaining forces whose values change with respect to the saltation phase.

It is clear from Fig. 3 that the greatest effect on the particle movement is due to the drag force and the submerged gravitational force. In addition, the Magnus force is relatively large, especially immediately after the collision when the angular velocity reaches the maximum. The Basset force is less than other forces for this particle size. The results of the forces' calculation reveal the important role of the particle rotation on the particle movement and prove that the particle rotation cannot be ignored.

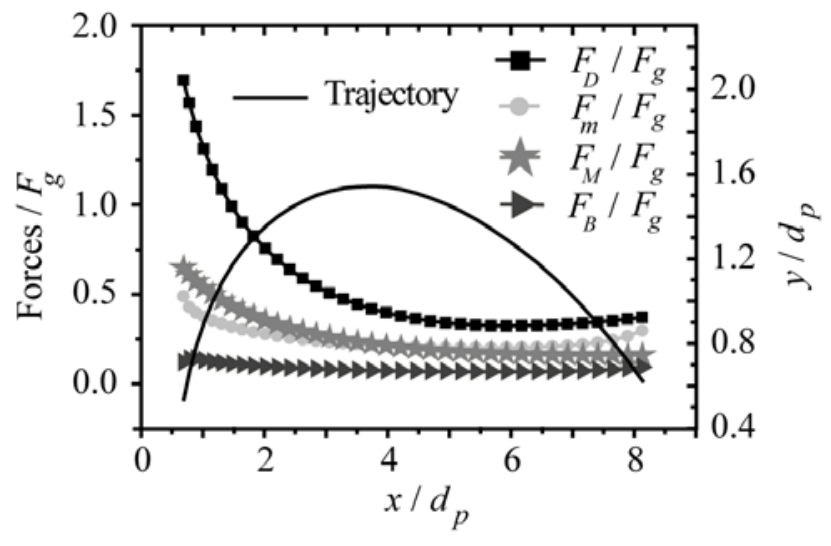

Fig. 3. The distributions of the forces acting on the particle during its typical trajectory $\left(d_{p}=6 \mathrm{~mm}, \rho_{p} / \rho=1.38\right.$, $u_{*}=0.00542 \mathrm{~m} \mathrm{~s}^{-1}$ ).

Obr. 3. Průběh sil působících na částici během její typické saltační trajektorie $\left(d_{p}=6 \mathrm{~mm}, \rho_{p} / \rho=1,38, u_{*}=0,00542\right.$ $\mathrm{m} \mathrm{s}^{-1}$ ).

\subsection{The comparison of the $3 D$ and $2 D$ model results}

The results of the 3D and 2D models were compared for identical conditions. For this reason, the new 2D model was developed by simplifying the presented 3D model. The value of the angle $\chi$ is equal to zero if its value belongs to the intervals $[0$; $\pi / 2)$ or $[3 \pi / 2 ; 2 \pi)$ and is equal to $\pi$ if its value belongs to the interval $[\pi / 2 ; 3 \pi / 2)$. Then, the contact zone is transformed from the spherical segment to the arc $\cup E O_{2} D$ (see Fig. 2a), which corresponds to the contact zone for the $2 \mathrm{D}$ model. The values of all the other parameters and coefficients in the $3 \mathrm{D}$ and 2D models are identical. This approach makes it possible to evaluate the effect of the model dimensionality alone.

The dimensionless mean values and standard deviations of the saltation length $\tilde{L}_{s}=L_{s} / d_{p}$ and height $\tilde{H}_{s}=H_{s} / d_{p}$ are shown in Fig. 4 , where $L_{s}$ and $H_{s}$ are the saltation length and height, respectively. The results of simulations calculated according to the 3D and 2D models are compared with the experimental data of Nino and Garcia (1998) for the natural sand particles in water for six values of the transport stage $\tau_{*} \tau_{*}$.

The calculations for both 2D and 3D numerical models were carried out under the initial physical conditions corresponding with the experiments of series S1 of Nino and Garcia (1998). The dimensionless mean values of saltation length and height of the 3D model simulation agree well with the 
experimental data, whereas the 2D model overestimates the saltation length and height. This is explained by the fact that, as a result of the particlebed collision, the particle impulse is transformed partly in the lateral direction, which cannot be described in the framework of the 2D approximation.

\subsection{The lateral particle dispersion}

The 3D model makes it possible to gain the values of saltation parameters, which cannot be calculated using 2D models. The lateral dispersion of particles can play an important role in some fluvial processes, for example, the development of a stable channel cross section (Ikeda et al., 1988), or the formation of longitudinal streaks observed in wide erodible-bed channels (Colombini, 1993).

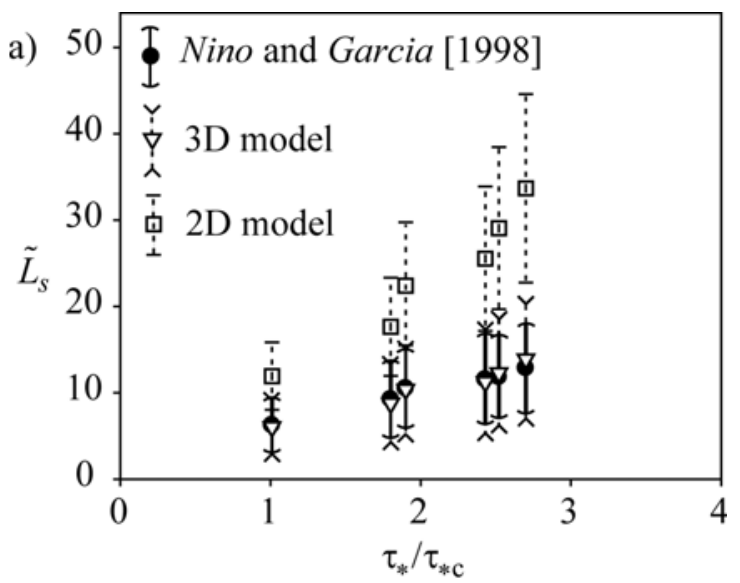

The particle trajectories have a random character and thus a bundle of them, which start from the same point named the bundle origin, was studied. Fig. 5a) illustrates such a bundle that gives an idea about the lateral dispersion of particles. A few tens of trajectories starting from the point with coordinates $x=0, y=h_{0}$, and $z=0$ were calculated. Let us define the bundle axis or its centreline as the mean deviations of the trajectories from the coordinate plane $O x y$. The bundle axis coincides with the coordinate axis $O x$ due to the flow symmetry. Let us also define the bundle boundaries (see Fig. 5b) as two standard deviations of the particle trajectories from the bundle axis in the cross sections. In this case, $95 \%$ of the particle trajectories lie between the bundle boundaries. The calculations show that the bundle boundaries are nearly the straight lines.

Fig. 4. Dimensionless saltation length (a) and height (b) (symbols represent mean value; vertical lines segments represent range of two standard deviations, i.e. $\pm \sigma$ ).

Obr. 4. Závislost bezrozměrné délky (a) a výšky saltace (b) (symboly representují střední hodnotu; svislé úsečky oblast dvou standardních odchylek, tj. $\pm \sigma$ ).
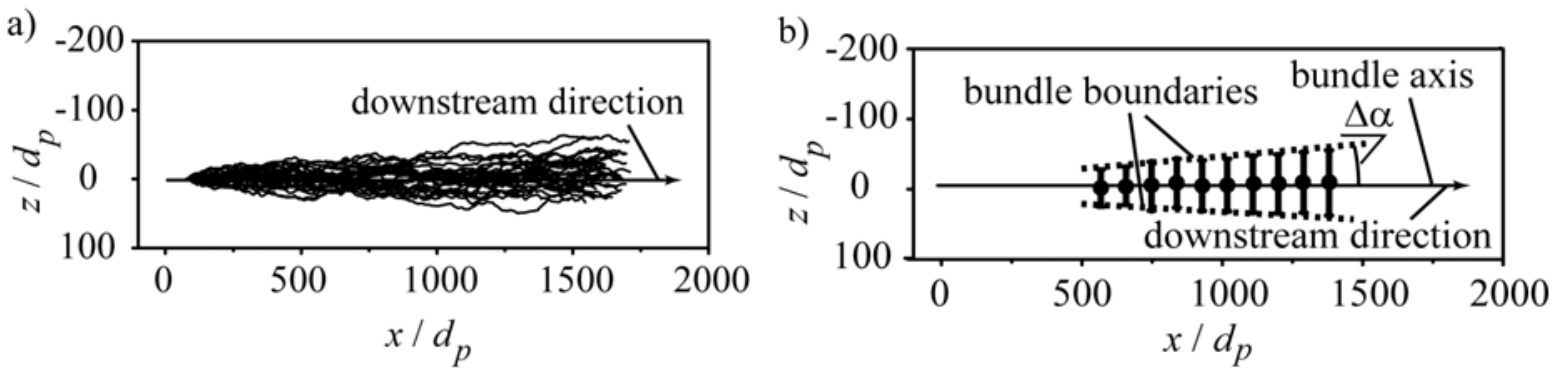

Fig. 5. The calculated lateral dispersion of saltating particles $\left(d_{p}=1 \mathrm{~mm}, \rho_{p} / \rho=2.65, k_{s}=1 \mathrm{~mm}, u_{*}=0.025 \mathrm{~m} \mathrm{~s}^{-1}\right)$; a) The bundle of saltating particles trajectories (view from the above), b) The bundle axis and bundle boundaries (symbols represent mean value; vertical lines segments represent range of four standard deviations, i.e. $\pm 2 \sigma$ ).

Obr. 5. Výpočet př́čné disperze, trajektorie částic pohybujících se saltací $\left(d_{p}=1 \mathrm{~mm}, \rho_{p} / \rho=2,65, k_{s}=1 \mathrm{~mm}, u_{*}=0,025 \mathrm{~m} \mathrm{~s}{ }^{-1}\right)$; a) hranice svazku trajektorií částic pohybujících se saltací (pohled shora), b) osa a hranice svazku trajektorií částic pohybujících se saltací (symboly representují střední hodnotu, svislé úsečky oblast čtyř standardních odchylek, tj. $\pm 2 \sigma$ ); (bundle axis - osa svazku trajektorií, bundle boundaries - hranice svazku trajektorií, downstream direction - směr proudu). 
The disperse angle $\Delta \alpha$ between the bundle boundary and its axis characterizes the particle lateral dispersion. For the simulation illustrated in Fig. 5, the disperse angle $\Delta \alpha$ is about $2.2^{\circ}$. It corresponds well to the value of $2.4^{\circ}$ published by Chara and Vlasak (2000).

The present 3D model was also used for the simulation of Nino and Garcia's (1998) experiments S21, S22, and S23, where particle motion was recorded from above. The calculated cumulative probability distribution of the absolute value of the instantaneous deviation angle, $\alpha_{d}$, from the downstream direction of the particle trajectories is shown in Fig. 6, where the experimental curve of Nino and Garcia (1998) is also introduced.

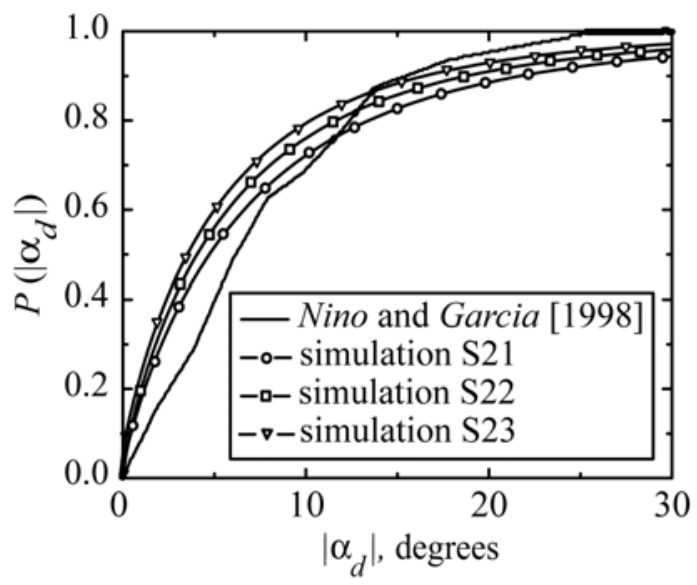

Fig. 6. Cumulative probability distribution function of absolute value of instantaneous deviation angle, $\alpha_{d}$, of particle trajectories with respect to the downstream direction (3D simulation of experiments S21, S22, S23 of Nino and Garcia (1998)).

Obr. 6. Kumulativní pravděpodobnostní distribuční funkce absolutní hodnoty okamžitého deviačního úhlu trajektorie částice, $\alpha_{d}$, od směru osy proudu (3D simulace experimentálních hodnot S21, S22, S23, Nino and Garcia, 1998).

The agreement of the calculated and experimental data is satisfactory, but for experiments the distribution seems to be independent of the dimensionless bed shear stress $\tau_{*}$, whereas the calculated curves have the clear-cut deviation for different values of $\tau$.

The mean absolute values of the deviation angle resulting from the experiments and simulation are plotted in Fig. 7. The absolute mean experimental values seem to be independent of $\tau *$ and equal to about 7.5 degrees. In contrast, the dependence of the calculated mean absolute values on $\tau *$ can be expressed as $\left|\alpha_{d}\right|=12.5-100 \tau_{*}$ in the studied range.

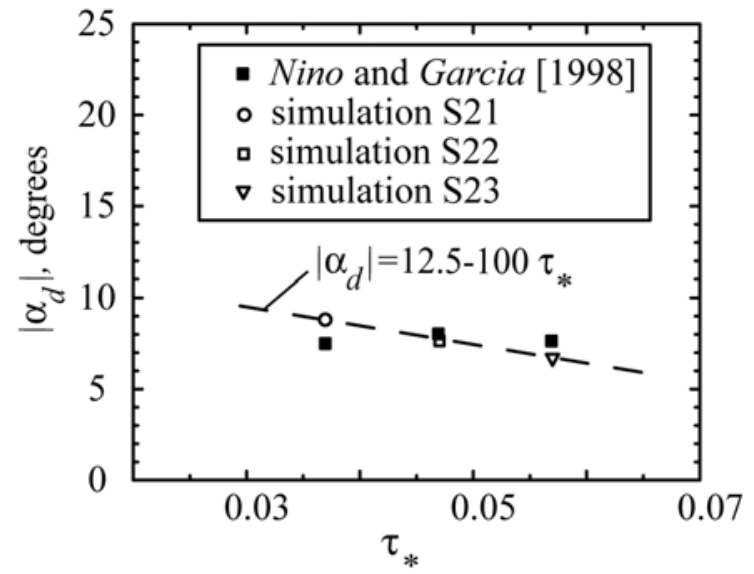

Fig. 7. Comparison of the measured and simulated absolute value of deviation angle $\left|\alpha_{d}\right|$.

Obr. 7. Srovnání měřených a vypočtených absolutních hodnot deviačního úhlu $\left|\alpha_{d}\right|$.

The differences between the results of the calculated and experimental values can be explained in the following way. Nino and Garcia (1998) state: "The deviations of the particle trajectories from the downstream direction seem to be caused by two mechanisms; the first is associated with the initial condition imparted by a collision with a bed particle, while the second would be related to cross-flow turbulent events." However, the model takes into account only the first mechanism.

The influence of the first mechanism on the deviation angle decreases with the increasing flow velocity (increases also in $u *$ and $\tau *$ ), since, after the particle rebounds from the bed, the higher water velocity straightens the particle trajectory to the downstream direction more intensely. The effect of the second mechanism increases the deviation angle since the turbulent fluctuations also increase with an increase in the flow velocity. If the change of both the mechanisms' contributions is nearly equal, then the mean value of the deviation angle does not change, and the experimental values seem to be independent of $\tau *$. The numerical model does not take into account the turbulent velocity fluctuations, i.e. the effect of the second mechanism is not included, but the first one decreases the deviation angle when $u *$ increases.

Nevertheless, the discrepancies between the calculated and experimental data even for particles with a size of $0.5 \mathrm{~mm}$ are small; therefore, the effect of turbulent fluctuations of the fluid velocity can be neglected, and the presented 3D model is acceptable. 


\section{Conclusions}

A 3D numerical model of spherical particle saltation in a channel with a rough fixed bed has been developed as an extension of the previous 2D model (Lukerchenko et al., 2006).

The spherical particle motion in the saltation process consists of translational motion in a fluid with simultaneous rotation around one of its diameters. During the saltation, the drag force, submerged gravitational force, Basset history force, force due to added mass, Magnus force, and drag torque act on the particle. The mutual influence of the translational and rotational motion is taken into account by means of the dependences of the drag force coefficient, drag torque coefficient, and Magnus force coefficient on both the translational and rotational Reynolds numbers.

A stochastic method is proposed for the calculation of the particle-bed collision in the 3D case. The collision height was determined as a random function of the particle radius $r_{p}$ and the channel bed roughness $k_{s}$. The contact zone was defined as the set of particle surface points at which the contact with the bed is possible during the relevant collision and the method for its calculation was proposed. The contact point was determined as the point with a random position in the contact zone.

The collision coordinate system was defined as a system in which the impulse equations have the simplest form, and the method of the coordinate system transformation from the initial coordinate system is proposed. In this coordinate system, the solution of the impulse equations for the 2D case can also be directly used for the 3D case.

The distributions of the forces, acting on the particle along its typical trajectory, are calculated for the saltation of the particle of $6 \mathrm{~mm}$ diameter in water. It is shown that, in this case, the drag force and the submerged gravitational force produce the main contributions to the saltation motion. The effect of the Magnus force is also significant, especially immediately after the collision, i.e. in the period when the angular velocity reaches its maximum value. This result confirms that the particle rotation plays an important role during the saltation and cannot be neglected.

The comparison of the calculated mean values of the saltation length and height with the experimental data of Nino and Garcia (1998) shows a good agreement and reveals that the 2D model overestimates the saltation length and height. This can be explained by the fact that the particle impulse re- sulting from the particle-bed collision is transformed partly in the lateral direction, which cannot be described by the 2D approximation.

For the study of the lateral dispersion of saltating particles, the concept of the bundle of particle trajectories starting from the same point was introduced and the disperse angle was defined as the angle between the bundle boundary and its axis. For the simulation of the saltation of particles with a diameter of $1 \mathrm{~mm}$, it was shown that the disperse angle is about $2.2^{\circ}$.

The deviation angles of the particle trajectory with respect to the downstream direction were calculated and compared with the experimental data of Nino and Garcia (1998) for the saltation of natural sand particles of size $0.5 \mathrm{~mm}$ in water. The calculated results agree well with the experimental data.

The present 3D model was developed for a fixed bed and its possible extension for a mobile bed can be a subject for further study.

\section{Appendix A: Algorithm of the particle trajec- tory calculation}

The physical parameters of the particle and the channel are defined:

- particle diameter $d_{p}$

- particle density $\rho_{p}$,

- fluid density $\rho$,

- fluid kinematic viscosity $v$,

- channel bed roughness $k_{s}$,

- shear velocity $u *$.

In time $t=0$ the initial conditions are:

- the coordinates of the particle center $O_{p}\left(x_{p}, y_{p}\right.$, $z_{p}$ ),

- the vector of the translational $\boldsymbol{v}\left(v_{x}, v_{y}, v_{z}\right)$ velocity,

- the vector of the angular $\omega\left(\omega_{x}, \omega_{y}, \omega_{z}\right)$ velocity.

A.1. The system of ordinary differential equations of the particle saltatory motion in the channel (see Eqs. (A5) -(A15)), Lukerchenko et al., 2006), together with Eqs. (1), (2) and (4) of the present paper is solved numerically using a fourth-order Runge-Kutta scheme.

A.2. The collision height $h_{c}$ is defined using the random-number generator in time $t=0$ (for first particle - bed collision) or, for the next hops, immediately after the previous collision.

A.3. The calculation of the particle motion in fluid flow is finished in the moment when the co- 
ordinate $y_{p}$ of the particle center becomes less or equal to the collision height $h_{c}$.

A.4. The vector of the particle translational velocity in this moment is used to define the contact zone for the particle - bed collision.

A.5. The contact point is calculated (see section 3.3).

A.6. The vectors of the particle translational $v\left(v_{x}\right.$, $\left.v_{y}, v_{z}\right)$ and angular velocities $\omega\left(\omega_{x}, \omega_{y}, \omega_{z}\right)$ are calculated in the collision coordinate system using the set of transformations of the coordinate systems specified in the section 3 .

A.7. The set of Eq. (11) is used to calculate the vectors of translational and angular particle velocities immediately after the collision.

A.8. After transformations of the vectors to the original coordinate system $O x y z$, they can be used as the initial conditions for the calculation of the subsequent trajectory of the particle; the calculation continues, see step A.1.

Acknowledgements. The authors gratefully acknowledge the support under the project No. GA103/06/1487 of the Grant Agency of the Czech Republic and the Institutional Research Plan AV0Z20600510 of the Academy of Sciences of the Czech Republic.

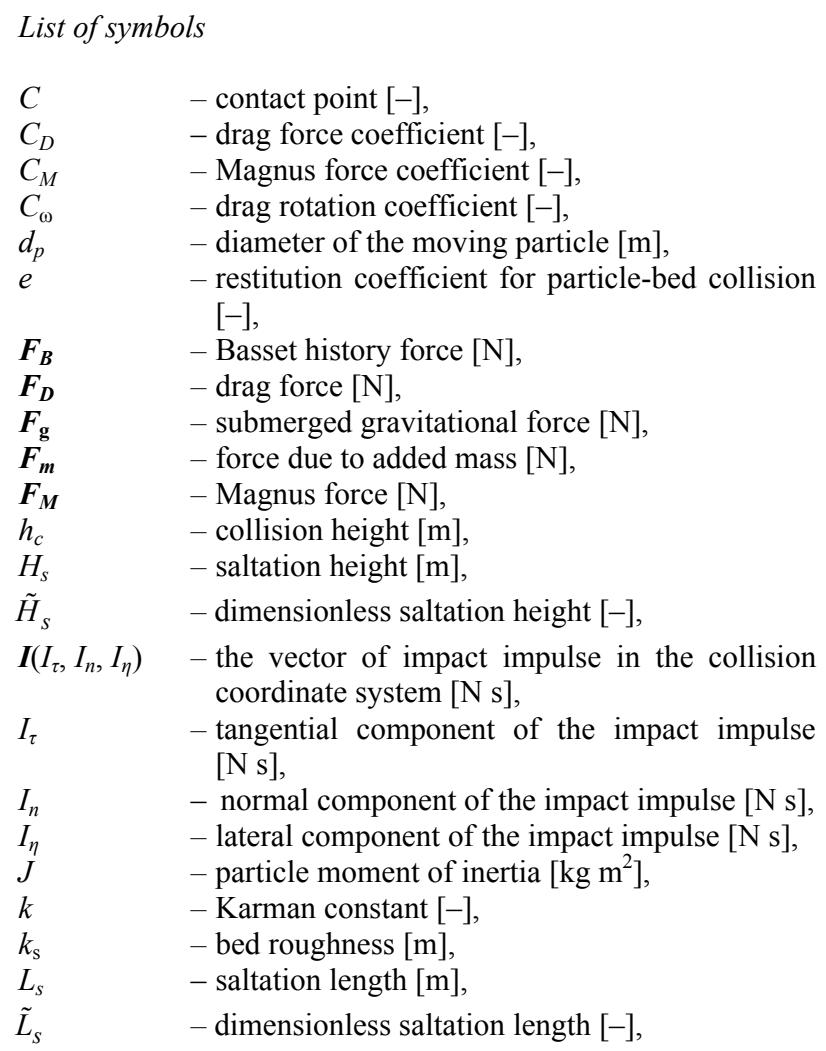

M - drag torque of viscous forces acting on a rotating particle in fluid $[\mathrm{N} \mathrm{m}]$

$m \quad-$ mass of the moving particle $[\mathrm{kg}]$,

$O_{p}\left(x_{p}, y_{p}, z_{p}\right)$ - particle centre [-],

$r_{p} \quad$ - radius of the moving particle [m],

$\boldsymbol{r}_{\boldsymbol{p}}\left(x_{p}, y_{p}, z_{p}\right)$ - radius-vector of the particle centre of mass [m],

$\operatorname{Re} \quad-$ translational Reynolds number [-],

$\operatorname{Re}_{\omega} \quad-$ rotational Reynolds number [-],

$u_{*} \quad-$ fluid shear velocity $\left[\mathrm{m} \mathrm{s}^{-1}\right]$,

$v_{f}\left(v_{f x}, v_{f y}, v_{f z}\right)$ - vector of the fluid velocity $\left[\mathrm{m} \mathrm{s}^{-1}\right]$,

$\boldsymbol{v}\left(v_{x}, v_{y}, v_{z}\right)$ - vector of velocity of the particle centre of mass $\left[\mathrm{m} \mathrm{s}^{-1}\right]$,

$v_{\boldsymbol{R}}-$ vector of the particle relative velocity $\left[\mathrm{m} \mathrm{s}^{-1}\right]$,

$v^{-}\left(v_{\tau}^{-}, v_{n}^{-}, v_{\eta}^{-}\right)-$vector of the particle translational velocity immediately before collision in the collision coordinate system $C \tau n \eta\left[\mathrm{m} \mathrm{s}^{-1}\right]$,

$\boldsymbol{v}^{+}\left(v_{\tau}^{+}, v_{n}^{+}, v_{\eta}^{+}\right)$- vector of the particle translational velocity immediately after collision in the collision coordinate system $C \tau n \eta\left[\mathrm{m} \mathrm{s}^{-1}\right]$,

$\alpha_{d} \quad-$ angle of the particle trajectory deviation from the downstream direction [degree],

$\Delta \alpha \quad-$ disperse angle [degree],

$\Gamma \quad-$ particle dimensionless angular velocity [-],

$\lambda_{11} \quad-$ added mass of the moving particle [kg],

$v \quad-$ kinematical viscosity $\left[\mathrm{m}^{2} \mathrm{~s}^{-1}\right]$,

$\rho \quad-$ fluid density $\left[\mathrm{kg} \mathrm{m}^{-3}\right]$,

$\rho_{p} \quad-$ density of the moving particle $\left[\mathrm{kg} \mathrm{m}^{-3}\right]$,

$\sigma \quad-$ standard deviation $[-]$,

$\tau_{*} \quad-$ dimensionless bed shear stress $[-]$,

$\tau_{* \mathrm{C}} \quad-$ dimensionless critical shear stress for sediment motion [-],

$\Omega \quad-$ particle volume $\left[\mathrm{m}^{3}\right]$,

$\boldsymbol{\omega}\left(\omega_{x}, \omega_{y}, \omega_{z}\right)-$ vector of angular velocity of the particle rota tion around its diameter $\left[\mathrm{s}^{-1}\right]$,

$\omega_{R}-$ vector of the particle relative angular velocity $\left[\mathrm{s}^{-1}\right]$,

$\omega^{-}\left(\omega_{\tau}^{-}, \omega_{n}^{-}, \omega_{\eta}^{-}\right)-$vector of the particle angular velocity immediately before collision in the collision coordinate system $C \tau n \eta\left[\mathrm{s}^{-1}\right]$,

$\omega^{+}\left(\omega_{\tau}^{+}, \omega_{n}^{+}, \omega_{\eta}^{+}\right)-$vector of the particle angular velocity immediately after collision in the collision coordinate system $C \tau n \eta\left[\mathrm{s}^{-1}\right]$.

\section{REFERENCES}

ANCEY C., BIGILLON F., FREY P., LANIER J., DUCRET R., 2002: Saltating motion of a bead in a rapid water stream. Phys. Rev. E, 66, 3, 036306, doi:10.1103/PhysRevE. 66.036306.

BAGNOLD R.A., 1973: The nature of saltation and of 'bedload' transport in water. Proc. R. Soc. London A, 332, 473-504.

BARKLA H.M., AUCHTERLONIE L.J., 1971: The Magnus or Robins effect on rotating spheres. J. Fluid Mech., 47, 437-447.

CHARA, Z., VLASAK P., 2000: Lateral dispersion of solid particles in water flow. Proc. Eng. Mech. 2000, Svratka (Czech Republic), 161-166.

COLOMBINI M., 1993: Turbulence-driven secondary flows and formation of sand ridges. J. Fluid Mech., 254, 701-719.

CROWE C.T., SOMMERFELD M., TSUJI Y., 1998: Multiphase flows with droplets and particles. CRC Press LLC, Boca Raton, London, New York, Washington, D.C., 471 pp. 
FRANCIS J.R.D., 1973: Experiments on the motion of solitary grains along the bed of a water stream. Proc. R. Soc. London A, 332, 443-471.

GOLDSHTIK M.A., SOROKIN V.N., 1968: On motion of particle in vortex chamber. (In Russian.) J. Appl. Math. Eng. Phys., 6, 149-152.

IKEDA S., PARKER G., KIMURA Y., 1988: Stable width and depth of self-formed straight gravel rivers with heterogeneous bed materials. Water Resour. Res., 24, 5, 713-722.

KHOLPANOV L.P., IBYATOV R.I., 2005: Mathematical modelling of the dispersed phase dynamics. Theor. Found. Chem. Eng., 39, 2, 190-199.

KUROSE R., MAKINO H., KOMORI S., 2001: Particle trajectory in turbulent boundary layer at high particle Reynolds number. J. Fluids Eng., ASME, 123, 956-958.

LEE H.-Y., HSU I.-S., 1994: Investigation of saltating particle motions. J. Hydraul. Eng., ASCE, 120, 7, 831-845.

LEE H.-Y., CHEN Y.-H., YOU J.-Y., LIN Y.-T., 2000: Investigation of continuous bed load saltating process. J. Hydraul. Eng., ASCE, 126, 9, 691-700.

LEE H.-Y., LIN Y.-T., CHEN Y.-H., YOU J.-Y., WANG H.-W., 2006: On three-dimensional continuous saltating process of sediment particles near the channel bed. J. Hydraul. Res., 44, 3, 374-389.

LUKERCHENKO N., CHARA Z., VLASAK P., 2006: 2D numerical model of particle-bed collision in fluid-particle flows over bed. J. Hydraul. Res., 44, 1, 70-78.

LUKERCHENKO N., KVURT Y., KHARLAMOV A., CHARA Z., VLASAK P., 2008a): Experimental evaluation of the drag force and drag torque acting on a rotating spherical particle moving in fluid. J. Hydrol. Hydromech., $56,2,88-94$.

LUKERCHENKO N., PIATSEVICH S., CHARA Z., and VLASAK P., 2008 b): Particle sorting during saltation in channel with transversely tilted bed. Proc. $14^{\text {th }}$ Int. Conf. Transport and Sediment. Solid Particles, June 23-27, 2008, Saint Petersburg (Russia), 186-193.

MATSUMOTO S., SAITO S., 1970: Monte Carlo simulation of horizontal pneumatic conveying based on the rough wall model. J. Chem. Engng. Japan, 3, 223-230.

MAXEY M.R., RILEY J.J., 1983: Equation of motion for a small rigid sphere in a nonuniform flow. Phys. Fluids, 26, 4, 883-889.

MEI R., ADRIAN R.J., HANRATTY T.J., 1991: Particle dispersion in isotropic turbulence under Stokes drag and Basset force with gravitational settling. J. Fluid Mech., 225, 481-495.

MICHAELIDES E.E., 2003: Hydrodynamic force and heat/mass transfer from particles, bubbles, and drops - the Freeman scholar lecture. J. Fluids Eng., ASME, 125, 209-238.

MURPHY P.J., HOOSHIARI H., 1982: Saltation in water dynamics. J. Hydraul. Eng., ASCE, 108, HY11, 1251-1267.

NINO Y., GARCIA M., 1994: Gravel saltation. 2. Modeling, Water Resour. Res., 30, 6, 1915-1924.

NINO Y., GARCIA M., 1998: Experiments on saltation of sand in water. J. Hydraul. Eng., ASCE, 124, 1014-1025.

NINO Y., GARCIA M., AYALA L., 1994: Gravel saltation. 1. Experiments, Water Resour. Res., 30, 6, 1907-1914.

OESTERLE B., 1989: Internal kinetic transfers in the dispersed phase of a low concentration suspension flow. Int. J. Multiphase Flow, 15, 155-171.

OESTERLE B., BUI DINH T., 1998: Experiments on the lift of a spinning sphere in the range of intermediate Reynolds numbers. Exp. Fluids, 25, 16-22.

REIZES J.A., 1978: Numerical study of continuous saltation. J. Hydraul. Eng., ASCE, 104, HY9, 1303-1321.

RUBINOV S., KELLER J., 1961: The transverse force on a spinning sphere moving in a viscous fluid. J. Fluid Mech., $11,447-459$.

SAWATZKI O., 1970: Das Stromungsfeld um eine rotierende Kugel. (In German.) Acta Mechanica, 9, 159-214.

SCHMEECKLE M.W., NELSON J.M., 2003: Direct numerical simulation of bedload transport using a local, dynamic boundary condition. Sedimentology, 50, 2, 279-301.

SCHMEECKLE M.W., NELSON J.M., PITLICK J., BENNETT J.P., 2001: Interparticle collision of natural sediment grains in water. Water Resour. Res., 37, 9, 2377-2391.

SEKINE M., KIKKAWA H., 1992: Mechanism of saltating grains, II. J. Hydraul. Eng., 118, 4, 536-558.

TSUJI Y., OSHIMA T., MORIKAWA Y., 1985a): Numerical simulation of pneumatic conveying in a horizontal pipe. KONA, 3, 38-51.

TSUJI Y., MORIKAWA Y., MIZUNO O., 1985b): Experimental measurements of the Magnus force on a rotating sphere at low Reynolds numbers. ASME J. Fluid Eng., 107, 484-488.

VAN RIJN L.C., 1984: Sediment transport. I. Bed load transport. J. Hydraul. Eng., 110, 10, 1431-1456.

WIBERG P.L., SMITH J.D., 1985: A theoretical model for saltating grains in water. J. Geophys. Res., 90, C4, 73417354.

Received 23. November 2008 Scientific paper accepted 19. February 2009

\section{D NUMERICKÝ MODEL SALTACE KULOVITÉ ČÁSTICE V KORYTĚ S PEVNÝM DRSNÝM DNEM}

Nikolaj Lukerčenko, Siarhej Piatsevič, Zdeněk Chára, Pavel Vlasák

V předložené studii je popsán vývoj 3D numerického modelu saltačního pohybu kulovité částice $\mathrm{v}$ kanále s pevným drsným dnem. Kulovitá částice (průměr $d_{p}$, hustota $\rho_{p}$ ) se pohybuje translačně a současně rotuje kolem svého těžiště $\mathrm{v}$ korytě s pevným drsným dnem v kapalině o hustotě $\rho$ a kinematické viskositě $v$.

Saltační pohyb částic je z fyzikální podstaty třírozměrný proces a kolize částice se dnem je hlavní mechanismus vzniku laterární disperze částic. Model byl vyvinut jako rozšíření 2D numerického modelu autorů ( $L u$ kerchenko et al., 2006), nebot' vektorová forma soustavy rovnic umožňuje využití tohoto systému i pro 3D případ. Předložený model předpokládá pevné dno, jeho prrípadné rozšiření na pohyblivé dno může být předmětem dalšího vývoje.

Saltační pohyb částice je možné rozdělit na dvě fáze volný pohyb částice $\mathrm{v}$ proudící vodě a kolizi částice se dnem. Na rozdíl od řady jiných modelů předložený model zahrnuje jak translační pohyb částice, tak i její současnou rotaci. Model je založen na systému rovnic popisujících síly a momenty působící na pohybující se rotující částici, tj. při saltačním pohybu částice v proudu kapa- 
liny působí na částici síla odporu kapaliny, gravitační síla na ponořenou částici, Bassetova síla, síla prídavné hmoty, Magnusova síla a dále moment vazkých sil působících na částici rotující kolem své osy úhlovou rychlostí $\omega$.

Podobně jako ve většině modelů vliv turbulentních fluktuací na pohyb částice není uvažován, nebot' bylo již dřive prokázáno, že pro částice větší než $0,5 \mathrm{~mm}$ je účinek turbulentních fluktuací možno zanedbat. Je-li koncentrace unášených částic nízká, lze zanedbat i jejich vzájemné kolise a vliv částic na proud kapaliny a pohyb všech částic může být representován pohybem jednotlivé částice.

Vzájemný vliv translačního a rotačního pohybu částice je vyjádřen pomocí závislosti koeficientů odporové síly, odporového momentu a Magnusovy síly (viz rov. (1), (2) a (4)) na obou Reynoldsových číslech, translačním $\operatorname{Re}=\left|v_{\boldsymbol{R}}\right| d_{p} / v$ a rotačním $\operatorname{Re}_{\omega}=\left|\omega_{\boldsymbol{R}}\right| r_{p}^{2} / v$, kde $\boldsymbol{v}_{\boldsymbol{R}} \mathrm{je}$ vektor relativní rychlosti částice a kapaliny, $\omega_{R}$ - relativní úhlová rychlost částice.

Byla navržena stochastická metoda pro výpočet pro 3D prrípad kolize částice se dnem. Složky translační a rotační rychlosti pohybující se částice po kolizi byly vyjádřeny jako funkce složek rychlosti těsně před kolizí. Kolizní výška byla definována jako náhodná funkce poloměru částice $r_{p}$ a drsnosti dna $k_{s}$. Pro 3D model byla definována kontaktní zóna jako kulová úseč $\mathrm{EO}_{2} \mathrm{D}$ (viz obr. 2a), tj. množina bodů na povrchu částice, v nichž kontakt částice s drsným dnem je možný během dané kolize a byl navržen způsob jejího výpočtu. Kontaktní bod byl určen jako bod s náhodnou polohou v kontaktní zóně.

Byl navržen systém transformace počátečního souřadného systému $O x y z$ (viz obr. 1) na kolizní souřadný

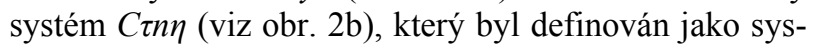
tém, v němž má soustava momentových rovnic (rov. (11)) nejjednodušší tvar. V tomto souřadném systému může být použito řešení odvozené pro $2 \mathrm{D}$ případ i pro 3D prípad.

Průběh sil působících na částici během jednoho skoku typické saltační trajektorie, který byl vypočten pro částice průměru $6 \mathrm{~mm}$ ve vodě (viz obr. 3) ukazuje, že na částici při saltačním pohybu má nejvýznamnější vliv odporová síla a na ponořenou částici gravitační síla. Účinek Magnusovy síly je významný zejména brzy po kolizi částice se dnem, tj. v době, kdy úhlová rychlost částice dosahuje maxima. To potvrzuje významnou roli rotace částice na saltační pohyb i to, že rotaci částice nelze zanedbat.

Srovnání středních hodnot saltační délky $\tilde{L}_{s}$ a výšky $\tilde{H}_{s}$ vypočtených na základě $3 \mathrm{D}$ modelu s výsledky 2D modelu a experimentálními daty (Nino, Garcia, 1998) ukazuje dobrou shodu experimentálních dat s výsledky 3D modelu a zároveň potvrzuje, že 2D model dává navýšené výsledky hodnot saltační délky a výšky, viz obr. 4. To lze vysvětlit tím, že impuls vyplývající z kolize části- ce se dnem je ve skutečnosti částečně přenášen do bočního pohybu, což nemůže být zahrnuto do $2 \mathrm{D}$ simulace.

Pro studium a popis laterární disperze částic při saltačním pohybu byl zaveden předpoklad svazku trajektorií částic procházejících (počínajících svůj pohyb) jedním bodem. Byl definován disperzní úhel $\Delta \alpha$ jako úhel mezi průmětem hranice svazku (obalové křivky trajektorií částic) a jeho osou do vodorovné roviny. Simulace saltačního pohybu částic průměru $d_{p}=1 \mathrm{~mm}$ ukázala, že hodnota disperzního úhlu v proudu charakterizovaném smykovou rychlostí $u_{*}=0,025 \mathrm{~m} \mathrm{~s}^{-1}$ je přibližně $2,2^{\circ}$ (viz obr. 5), což je v dobré shodě s dř́ive určenými experimentálními hodnotami.

Byl uskutečněn i výpočet deviačního úhlu $\alpha_{p}$, tj. úhlu mezi trajektorií částice a osou proudu a jeho porovnání $\mathrm{s}$ experimentálními daty pro saltační pohyb př́rodního písku s průměrem zrn $0,5 \mathrm{~mm}$ v proudu vody (Nino, Garcia, 1998). Také v tomto prrípadě je shoda vypočtených hodnot $\mathrm{s}$ experimentálními daty uspokojivá (viz obr. 6 a 7).

$$
\begin{aligned}
& \text { Seznam symboli } \\
& C \quad-\text { kontaktní bod }[-] \text {, } \\
& C_{D} \quad-\text { odporový koeficient částice [-], } \\
& C_{M} \quad-\text { koeficient Magnusovy síly [-], } \\
& C_{\omega} \quad-\text { odporový koeficient rotující částice pohybující } \\
& \text { se translačně }[-] \text {, } \\
& d_{p} \quad-\text { průměr pohybující se částice }[\mathrm{m}] \text {, } \\
& e-\text { koeficient restituce pro kolizi částice se dnem } \\
& {[-] \text {, }} \\
& \boldsymbol{F}_{\boldsymbol{B}} \quad-\text { Bassetova síla }[\mathrm{N}], \\
& \boldsymbol{F}_{\boldsymbol{D}} \quad-\text { odporová síla }[\mathrm{N}], \\
& \boldsymbol{F}_{\mathbf{g}} \quad-\text { gravitační síla na ponořenou částici }[\mathrm{N}] \text {, } \\
& \boldsymbol{F}_{\boldsymbol{m}} \quad-\text { síla prídavné hmoty }[\mathrm{N}], \\
& \boldsymbol{F}_{\boldsymbol{M}} \quad-\text { Magnusova síla }[\mathrm{N}], \\
& h_{c} \quad-\text { kolizní výška }[\mathrm{m}], \\
& H_{s} \quad-\text { výška saltace }[\mathrm{m}] \text {, } \\
& \tilde{H}_{s} \quad-\quad \text { bezrozměrná výška saltace }[-] \text {, } \\
& \boldsymbol{I}\left(I_{\tau}, I_{n}, I_{\eta}\right) \text { - vektor momentu impulsu v kolizním souřad- } \\
& \text { ném systému }[\mathrm{N} \mathrm{s}] \text {, } \\
& I_{\tau} \quad-\text { tangenciální složka momentu impulsu [N s], } \\
& I_{n} \quad-\text { normální složka momentu impulsu [N s], } \\
& I_{\eta} \quad-\text { laterální složka momentu impulsu [N s], } \\
& J \quad-\text { moment setrvačnosti částice }\left[\mathrm{kg} \mathrm{m}^{2}\right] \text {, } \\
& k \quad-\text { Karmánova konstanta }[-] \text {, } \\
& k_{\mathrm{S}} \quad-\text { drsnost dna }[\mathrm{m}] \text {, } \\
& L_{s} \quad-\text { délka saltace }[\mathrm{m}] \text {, } \\
& \tilde{L}_{s} \quad-\text { bezrozměrná délka saltace }[-] \text {, } \\
& \text { M - moment vazkých sil působící na rotující částici } \\
& \mathrm{v} \text { kapalině }[\mathrm{N} \mathrm{m}] \text {, } \\
& M \quad-\text { hmota pohybující se částice }[\mathrm{kg}] \text {, } \\
& O_{p}\left(x_{p}, y_{p}, z_{p}\right)-\text { střed (těžiště) pohybující se částice [-], } \\
& r_{p} \quad-\text { poloměr pohybující se částice }[\mathrm{m}] \text {, } \\
& \boldsymbol{r}_{\boldsymbol{O}}\left(x_{p}, y_{p}, z_{p}\right) \text { - poloměr -vektor těžiště pohybující se částice } \\
& {[\mathrm{m}] \text {, }} \\
& \text { Re - Reynoldsovo číslo při translačním pohybu } \\
& \text { částice [-], } \\
& \operatorname{Re}_{\omega}-\text { Reynoldsovo číslo při rotačním pohybu [-], } \\
& u_{*} \quad-\text { smyková rychlost }\left[\mathrm{m} \mathrm{s}^{-1}\right] \text {, } \\
& v_{f}\left(v_{f x}, v_{f y}, v_{f z}\right) \text { - vektor rychlosti kapaliny }\left[\mathrm{m} \mathrm{s}^{-1}\right] \text {, }
\end{aligned}
$$




\begin{tabular}{|c|c|}
\hline $\boldsymbol{v}\left(v_{x}, v_{y}, v_{z}\right)$ & -vektor rychlosti těžiště částice $\left[\mathrm{m} \mathrm{s}^{-1}\right]$, \\
\hline & - vektor relativní rychlosti částice $\left[\mathrm{m} \mathrm{s}^{-1}\right.$ \\
\hline \multicolumn{2}{|c|}{$\begin{aligned} \boldsymbol{v}^{-}\left(v_{\tau}^{-}, v_{n}^{-}, v_{\eta}^{-}\right)- & \text {vektor translační rychlosti částice těsně před } \\
& \text { dopadem částice } \mathrm{v} \text { kolizním souřadném } \\
& \text { systému } C \tau n \eta\left[\mathrm{m} \mathrm{s}^{-1}\right],\end{aligned}$} \\
\hline & 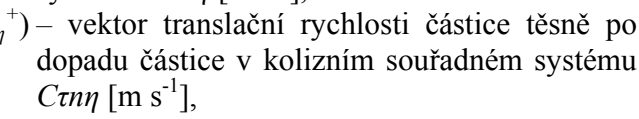 \\
\hline$\alpha_{d}$ & $\begin{array}{l}\text { - deviační úhel trajektorie čá } \\
\text { osou svazku trajektorií části } \\
\text { [stupeň], }\end{array}$ \\
\hline$\Delta \alpha$ & $\begin{array}{l}\text { - disperzní úhel - úhel mezi projekcí hranice a } \\
\text { osy svazku na rovinu dna [stupeň], }\end{array}$ \\
\hline$\Gamma$ & $\begin{array}{l}\text { - bezrozměrná úhlová rychlost rotující částice } \\
\text { [-], }\end{array}$ \\
\hline & - přídavná hmota pohybující s \\
\hline & - součinitel kinematické viskozity $\left[\mathrm{m}^{2}\right.$ \\
\hline
\end{tabular}

$\rho \quad-$ hustota kapaliny $\left[\mathrm{kg} \mathrm{m}^{-3}\right]$,

$\rho_{p} \quad-$ hustota pohybující se částice $\left[\mathrm{kg} \mathrm{m}^{-3}\right]$,

$\sigma \quad-$ standardní odchylka [-],

$\tau_{*} \quad-$ bezrozměrné tečné napětí na dně kanálu [-],

$\tau_{*} \mathrm{C} \quad-$ bezrozměrné kritické tečné napětí pro fázi pohybu sedimentu [-],

$\Omega \quad$ - objem pohybující se částice $\left[\mathrm{m}^{3}\right]$,

$\boldsymbol{\omega}\left(\omega_{x}, \omega_{y}, \omega_{z}\right)-$ vektor úhlové rychlosti rotující částice $\left[\mathrm{s}^{-1}\right]$,

$\omega_{R} \quad-$ vektor relativní úhlové rychlosti částice $\left[\mathrm{s}^{-1}\right]$,

$\omega^{-}\left(\omega_{\tau}^{-}, \omega_{n}^{-}, \omega_{\eta}^{-}\right)-$vektor úhlové rychlosti rotující částice těsně před dopadem částice $\mathrm{v}$ kolizním souřadném systému $C \tau n \eta\left[\mathrm{s}^{-1}\right]$,

$\omega^{+}\left(\omega_{\tau}^{+}, \omega_{n}^{+}, \omega_{\eta}^{+}\right)-$vektor úhlové rychlosti rotující částice těsně po dopadu částice $\mathrm{v}$ kolizním souřadném systému $C \tau n \eta\left[\mathrm{s}^{-1}\right]$. 